EETP Vol. 14, 2019, №. 2(52)

ISSN 1896-2327 / e-ISSN 2353-7787

DOI: $10.35765 /$ eetp.2019.1452.02

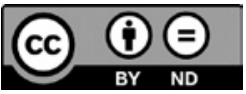

Nadesłano: 07.05.2019

Zaakceptowano: 31.07 .2019

Sugerowane cytowanie: Sikorska I., Adamczyk-Banach M., Polak M. (2019). Zasoby odporności psychicznej dziecka - co wiedzą o nich rodzice i nauczyciele, „Edukacja Elementarna w Teorii i Praktyce", vol. 14, nr 2(52), s. 23-39. DOI: 10.35765/eetp.2019.1452.02

\title{
Iwona Sikorska
}

ORCID: 0000-0002-1309-8065

Uniwersytet Jagielloński, Instyłut Psychologii Stosowanej

\section{Magdalena Adamczyk-Banach \\ ORCID: 0000-0002-7854-3676 \\ Uniwersytet Jagielloński, Instyłut Psychologii Stosowanej}

\section{Mateusz Polak}

\section{Zasoby odporności psychicznej dziecka - co wiedza o nich rodzice i nauczyciele}

\section{Children's Mental Resilience - What Do Parents and Teachers Know About It?}

\section{SŁOWA KLUCZOWE ABSTRAKT}

\footnotetext{
odporność Rozwój dziecka i postępy przez nie czynione są przedmiotem żywepsychiczna, go zainteresowania bliskich mu dorosłych - rodziców i nauczycieli. dzieciństwo, wiedza Celem prezentowanego badania było poszukiwanie odpowiedzi na o rozwoju pytanie o wiedzę rodziców i nauczycieli dziecka w wieku przedszkolnym na temat jego odporności psychicznej. Była ona zdefiniowana jako czynniki ochronne - inicjatywa, samokontrola i przywiązanie oraz czynniki ryzyka w postaci zachowań niepokojących. Uczestnikami badania byli rodzice i nauczyciele 335 dzieci w wieku 2-6 lat. W badaniu wykorzystano skalę obserwacyjną DECA (The Devereux Early Childhood Assessment) przeznaczoną dla dzieci w wieku od 2,0 lat do 5 lat i 11 miesięcy. Narzędzie składa się z 37 pozycji, wypełniane jest przez rodziców dziecka oraz jego nauczyciela przedszkolnego.
} 
Uzyskane wyniki wykazały różnice w zakresie oceny przez dorosłych zarówno czynników ochronnych, jak i czynników ryzyka: matki oceniły najwyżej inicjatywę dzieci, wyższe wymagania w zakresie samokontroli dzieci zaobserwowano u ojców w porównaniu z matkami i nauczycielami. Przywiązanie jako trzeci czynnik ochronny zostało ocenione wyżej przez rodziców niż przez nauczyciela. Nauczyciele zauważyli istotnie mniej zachowań trudnych u dzieci niż matki. W zakresie zachowań niepokojących stwierdzono tendencję nauczycieli do spostrzegania chłopców w sposób stereotypowy jako mniej grzecznych niż dziewczynki.

Okazało się, że wiedza matek, ojców i nauczycieli na temat zasobów odporności psychicznej dziecka różni się w istotny sposób. Może to także wynikać z odmiennego zachowania dziecka w środowisku przedszkolnym i domowym oraz z wpływu czynników społecznych.

\section{KEYWORDS ABSTRACT}

mental resilience,

Children's development and achievements are of great interest to childhood, their adult significant others, notably parents and teachers. The aim knowledge about of the presented research was to investigate what parents and teachers development of preschool children know (and fail to know) about the children's psychological resiliency - defined via the protective factors of initiative, self-control and attachment, as well as risk factors in the form of behavioral concerns.

The research was conducted among the parents and teachers of 335 preschool children aged 2-6 years. The study used the observational Devereux Early Assessment Scale, suitable for children aged 2 years 0 months -5 years 11 months. The scale consists of 37 items and is filled in by the children's parents and preschool teachers.

Significant differences were obtained in how parents and teachers assess children's protective factors and behavioral concerns. Mothers provided the highest scores of children's initiative, as compared to fathers and teachers. Fathers had higher expectations of a child's self-control than mothers and teachers. Attachment was scored higher by parents than teachers, who, on the other hand, reported more behavioral concerns in children than their parents. Moreover, teachers had a tendency to stereotypically perceive boys as demonstrating more behavioral concerns than girls - which was not observed in parents. The results indicate that the knowledge and perception of children's resiliency demonstrated by their teachers, mothers and fathers significantly varies, suggesting that these observers apply different judgment standards, and/or that children demonstrate different levels of protective factors and behavioral concerns at home vs. at preschool, due to the social-psychological factors. 
Wszystkie dzieci potrzebują odporności, nie tylko te żyjące w sytuacji ryzyka. Czasem tragedia, katastrofa żywiołowa, śmierć w rodzinie, rozwód czy choroba przychodzi niespodziewanie. Wówczas to dziecko rzeczywiście potrzebuje silnych czynników ochronnych i umiejętności radzenia sobie.

(LeBuffe i Naglieri 1999: 14)

\section{Wprowadzenie}

\section{Odporność psychiczna}

Rozwój dziecka i postępy przez nie czynione są przedmiotem żywego zainteresowania bliskich mu dorosłych - rodziców i nauczycieli przedszkola, a potem szkoły. Oprócz rozwoju poznawczego coraz większą uwagę przywiązują oni także do umiejętności społecznych czy kompetencji emocjonalnych. Wśród zasobów osobowych szczególne miejsce zajmuje odporność psychiczna, która potrzebna jest dziecku w radzeniu sobie z porażką, frustracją, stresem codziennym w konfliktach rówieśniczych. Odporność psychiczna jest jednym z tłumaczeń pojęcia resilience oznaczającego pozytywny rozwój mimo życia w niesprzyjających warunkach, zdolność adaptacji do skrajnie trudnych sytuacji czy też powrót do zdrowia, równowagi po doświadczeniach zagrożenia lub zniszczenia (Garmezy 1971; Rutter 1979; Luthar 1991; Werner i Smith 1992, 2001; Masten 2001; Olsson i in. 2003). Inne propozycje polskiego tłumaczenia to prężność (Heszen i Sęk 2007), sprężystość (Kaczmarek 2011; Ogińska-Bulik i Juczyński 2011) czy rezyliencja (Junik 2013). Szersze rozumienie terminu resilience dotyczy podejmowania zadań rozwojowych oraz radzenia sobie z codziennym stresem i adaptacji do wyzwań niesionych przez życie (Wustmann 2004, Fröhlich-Gildhoff, Dörner i Rönnau 2007/2012).

Wyniki ponad 50-letnich już badań nad odpornością psychiczną na świecie pozwoliły na zidentyfikowanie czynników, które pełnią funkcję ochronną dla zdrowia psychicznego dzieci. Są to: towarzyskość jako zmienna temperamentalna, dobry poziom funkcjonowania procesów poznawczych, wysoki poziom motywacji w zakresie planów i celów życiowych oraz edukacyjnych, pozytywny obraz siebie, pogodne i optymistyczne nastawienie do świata, dobre mechanizmy samokontroli, dobrze rozwinięte umiejętności społeczne (Garmezy 1983; Constantine, Bernard i Diaz 1999; Masten 2001; Werner i Smith 2001; Fergus i Zimmerman 2005). W programach profilaktycznych wzmacniania odporności dzieci znajdują się propozycje zabaw i ćwiczeń dotyczących takich obszarów jak: spostrzeganie siebie i innych (adekwatna percepcja mocnych i słabych stron), sprawstwo (inicjatywa, podejmowanie decyzji), umiejętność radzenia sobie ze stresem i osiągania relaksu, umiejętność rozwiązywania 
problemów (twórczość i pomysłowość) oraz umiejętności społeczne (nawiązywanie kontaktów, proszenie o pomoc) (Fröhlich-Gildhoff, Dörner i Rönnau 2007/2012; Sikorska, Sajdera i Paluch-Chrabąszcz 2017).

\section{Wiedza rodziców o rozwoju dzieci}

Analizując wiedzę rodziców na temat rozwoju dziecka w zakresie normatywnym, a wiedzę rodziców na temat rozwoju własnego dziecka, należy po pierwsze przyjrzeć się obszarom, które są lepiej poznane i cenione przez dorosłych, po drugie zaś rozważyć, na ile ta wiedza jest obiektywna, a w jakim stopniu zmieniona tendencją do przeceniania osiągnięć swojego potomka, po trzecie zaś zastanowić się, czy w porównaniu z nauczycielami rodzice potrafią trafniej oszacować umiejętności swoich pociech.

Badania nad przekonaniami i wiedzą rodziców na temat rozwoju dzieci prowadzone intensywnie w latach 90. ubiegłego wieku dotyczyły najczęściej rozwoju poznawczego. Porównania międzykulturowe wykazały, iż rodzice anglo-amerykańscy wyżej cenili zdolności poznawcze niż inne, choć nie musiało się to wiązać z dobrymi ocenami w szkole. Rodzice Latynosi i Azjaci deklarowali natomiast, że motywacja oraz umiejętności społeczne są równie ważne jak poznawcze (Okagaki i Sternberg 1993). Zaobserwowanie różnic w poglądach rodzicielskich jest o tyle istotne, że wpływają one na zróżnicowanie koncepcji wychowania dziecka, przekazywania mu wartości i wskazywania celów. Stwierdzono również, że matki lepiej orientują się w zachowaniach charakterystycznych dla dzieci młodszych, przed czwartym rokiem życia, niż starszych (Oliva i Palacios 1992).

W wielu badaniach opinie tych dwu grup: rodziców i nauczycieli były porównywane. Badania nad kompetencją komunikacyjną dzieci wykazały, iż matki w porównaniu z nauczycielkami istotnie wyżej oceniały zdolności komunikacyjne dzieci (Kielar-Turska 1995). Badacze wyjaśniają wynik tym, że nauczycielki w swojej ocenie odnosiły sprawność dziecka do modelu sprawności komunikacyjnych typowego dziecka w danym wieku i wskazywały na rozbieżność konkretnych osiągnięć z modelem. Matki bazowały podczas oceniania na oczekiwaniach wobec swojego dziecka, co powodowało przecenianie jego umiejętności.

W zakresie oceny przez dorosłych różnych właściwości rozwojowych dzieci stwierdzono, że: 1) matki oceniają rzetelniej możliwości rozwojowe przeciętnego niż własnego dziecka (które często przeceniaja), 2) nauczyciele natomiast rzetelniej szacują średni poziom właściwości poznawczych „dzieci w ogóle” niż osiągnięcia konkretnego dziecka (Miller 1991, Davis 1992 za: Kielar-Turska 1993), 3) ocena nauczyciela jest dokładniejsza niż ocena matki zarówno w przypadku oceny dziecka przeciętnego, jak i konkretnego. 


\section{Wiedza nauczycieli o rozwoju dzieci}

Aktualna wiedza z obszaru psychologii rozwojowej, wraz z umiejętnościami zastosowania jej w praktyce, jest uważana za bardzo istotny aspekt pracy nauczyciela. Kawecki (2013) zwraca uwagę na fakt, że dzisiejszy nauczyciel coraz częściej styka się z uczniami przejawiającymi różne trudności czy deficyty o charakterze rozwojowym lub społecznym. Łączenie kompetencji pedagogicznych i psychologicznych ułatwia profilaktykę zachowań problemowych oraz pełne wykorzystanie potencjału ucznia. Wczesne zaobserwowanie trudności, wynikających np. z niedostatecznej dojrzałości szkolnej dziecka, pozwala zapobiec wystąpieniu poważnych zaburzeń w przyszłości (Knap-Stefaniuk 2017). I przeciwnie - wczesna identyfikacja dzieci uzdolnionych pomoże we właściwym kierowaniu ich procesem edukacji (Szada-Borzyszkowska 2008). Niedostateczna wiedza na temat rozwoju dziecka utrudnia natomiast formułowanie wniosków i opinii dotyczących sytuacji ucznia, analizowanie i rozwiązywanie problemów wychowawczych czy korzystanie z dostępnej literatury (Knap-Stefaniuk 2017).

Z badań Stawinogi (2015) wynika, że polscy nauczyciele czerpią wiedzę o dziecku przede wszystkim z obserwacji jego zachowania. Oceniając właściwości rozwojowe sześciolatka, nauczyciele skupiają się na jego ogólnej sprawności fizycznej, poziomie czynności samoobsługowych, zwiększającej się zdolności dowolnej koncentracji, rozwoju mowy, umiejętności współpracy. Aspekty, na które najmniej zwracają uwagę, to m.in.: zdolność dostrzegania relacji przyczynowo-skutkowych, umiejętność asertywnego wyrażania sprzeciwu, sygnalizowania potrzeb, ujawnianie reakcji adekwatnych do sytuacji, spontaniczność, zdolność radzenia sobie w sytuacjach społecznych, rosnąca stabilność emocjonalna czy też ciekawość poznawcza i samodzielność. Są to czynniki, które w nierozerwalny sposób wiążą się z odpornością psychiczną, w tym z wszystkimi jej wymiarami uwzględnionymi w naszym badaniu: inicjatywą, samokontrolą, przywiązaniem oraz zachowaniami problemowymi. Tymczasem dla efektywnego nauczania ważny jest nie tylko rozwój poznawczy, ale także emocjonalno-społeczny (Daniels i Shumow 2003); coraz częściej dostrzegają to zarówno pedagodzy, jak i rodzice (Rahmawati, Tairas i Nawangsari 2018).

Doniesienia z badań dotyczących różnic w postrzeganiu dziecka przez rodziców i nauczycieli cechuje niespójność. Niektóre wyniki dowodzą, że rodzice i pedagodzy w podobny sposób oceniają zasoby dziecka, rezultaty innych badań wskazują natomiast, iż rodzice widzą swoje dziecko bardziej optymistycznie. Podczas gdy nauczyciele przyczyny trudności ucznia często upatrują w jego stałych, indywidualnych cechach, rodzice mają skłonność do wyjaśniania w ten sposób jego sukcesów, porażki przypisując czynnikom przemijającym (Kärkkäinen 2011). I chociaż pedagodzy mogą widzieć dziecko bardziej adekwatnie i trafniej niż rodzice oceniać jego umiejętności, to taki sposób postrzegania ucznia niesie za sobą ryzyko nadmiernie pesymistycznego, 
deterministycznego i stereotypowego myślenia o wychowankach (Buchanan i in. 1990; Katz 1997). Należy także pamiętać, że zdanie nauczyciela ma bardzo duży wpływ na samoocenę dziecka i jego przekonania na temat swoich umiejętności (Spinath i Spinath 2005), a dobra relacja między pedagogiem a dzieckiem pozytywnie wpływa m.in. na oczekiwania ucznia wobec nauki, adaptację do szkoły i jego samodzielność (Pianta i Sternberg 1992; Birch i Ladd 1997; Daniels, Kalkman i McCombs 2001). Tym ważniejsze jest, aby nauczyciel wyrażał się na temat możliwości dziecka w sposób pozytywny, potrafił identyfikować, nazywać i rozwijać jego mocne strony oraz jak najwcześniej wprowadzać profilaktykę potencjalnych zachowań problemowych.

Celem prezentowanego badania było poszukiwanie odpowiedzi na pytanie o wiedzę rodziców i nauczycieli dziecka w wieku przedszkolnym na temat jego odporności psychicznej. Była ona zdefiniowana jako czynniki ochronne - inicjatywa, samokontrola i przywiązanie oraz czynniki ryzyka w postaci zachowań niepokojących. Szczegółowe pytania badawcze brzmiały:

1. Czy wiedza matki, ojca i nauczyciela na temat zasobów odporności psychicznej dziecka, całościowa oraz w postaci poszczególnych składowych, różni się istotnie?

2. Czy dziewczynki oceniane są przez dorosłych inaczej niż chłopcy?

\section{Metoda}

Projekt uzyskał akceptację Komisji Etycznej Instytutu Psychologii Stosowanej Uniwersytetu Jagiellońskiego. Badanie było prowadzone za zgodą rodziców i nauczycieli, z zapewnieniem poufności oraz wszelkiego poszanowania danych osobowych. Rodzice i nauczyciele wypełniali skalę obserwacyjną indywidualnie i zwracali ją badaczowi w zamkniętej kopercie.

Pomiary z wykorzystaniem skali obserwacyjnej DECA przeprowadzono na próbie 335 dzieci w wieku przedszkolnym (wiek 2-6 lat, $\mathrm{M}=4,33$; $\mathrm{SD}=1,32$ ), w tym 146 dziewczynek i 189 chłopców. Skalę obserwacyjną wypełniały matki, ojcowie i nauczyciele każdego z dzieci. Matki $(\mathrm{N}=309)$ w wieku 23-47 lat $(\mathrm{M}=34,7$; $\mathrm{SD}=4,4)$ charakteryzowały się zróżnicowanym wykształceniem (jedna z wykształceniem podstawowym [1], 19 z zawodowym [2], 75 z wykształceniem średnim [3] oraz 215 z wykształceniem wyższym [4]). Ojcowie ( $\mathrm{N}=304) \mathrm{w}$ wieku 24-54 lat $(\mathrm{M}=36,5$; $\mathrm{SD}=4,7)-3 \mathrm{z}$ wykształceniem podstawowym, $43 \mathrm{z}$ wykształceniem zawodowym, 93 z wykształceniem średnim oraz 165 z wykształceniem wyższym. Skalę obserwacyjną dla 318 dzieci wypełnili również ich nauczyciele przedszkolni w wieku 30-54 lat o stażu pracy 5-28 lat. Dzieci i nauczyciele pochodzili z dziewięciu różnych instytucji oświatowych na terenie Krakowa i okolicznych miejscowości. Należy przy tym 
wspomnieć, że nie dla wszystkich dzieci zebrano informacje zarówno od matek, ojców, jak i nauczycieli (braki danych wynosiły około 10\%). Analizy statystyczne przeprowadzono tylko w przypadkach, w których skalę obserwacyjną dla danego czynnika (inicjatywy, samokontroli, przywiązania lub zachowań niepokojących) wypełniły poprawnie przynajmniej dwie osoby (ojciec, matka i nauczyciel).

W badaniu wykorzystano skalę obserwacyjną DECA (The Devereux Early Childhood Assessment) przeznaczoną dla dzieci w wieku od 2,0 do 5 lat i 11 miesięcy. Narzędzie składa się z 37 pozycji, wypełniane jest przez rodziców dziecka oraz jego nauczyciela przedszkolnego. Oceniana jest częstotliwość zachowań dziecka w ostatnich czterech tygodniach na skali pięciostopniowej: „nigdy-rzadko-czasami-często-bardzo często”. Narzędzie bada odporność psychiczną w czterech obszarach: 1) Inicjatywa (Initiative), 2) Samokontrola (Self-control), 3) Przywiązanie (Attachment) oraz 4) Zachowania niepokojące (Behavioral concerns). Spójność wewnętrzna dla Indeksu Czynników Ochronnych (Total Protective Factors Scale), łączącego trzy pierwsze wymiary, wynosi dla rodziców $\alpha=0,91$, a dla nauczycieli $\alpha=0,94$. Alfa Cronbacha dla pozostałych podskal wynosi $\alpha=0,80$ dla rodziców i $\alpha=0,84$ dla nauczycieli.

Skala DECA uważana jest za narzędzie badania przesiewowego, które ma na celu po pierwsze określenie czynników ochronnych dziecka w środowisko domowym i szkolnym, po drugie wsparcie rodziców i nauczycieli we wzmacnianiu odporności psychicznej dziecka, po trzecie zaś wychwycenie dzieci przejawiających zachowania niepokojące, zanim rozwiną się z nich zaburzenia. Skala ta była wykorzystywana w badaniach z udziałem dzieci z grupy ryzyka, m.in. w amerykańskim projekcie Head Start (Ogg, Brinkman, Dedrick i Carlson 2010), dotyczących zdrowia psychicznego (LeBuffe i Shapiro 2004), gotowości szkolnej (Ansari i Winsler 2014) oraz wczesnej samoregulacji i związanych z nią problemów behawioralnych (Sawyer, Miller-Lewis, Searle, Sawyer i Lynch 2015).

\section{Wyniki}

Analizę przeprowadzono z wykorzystaniem ogólnego modelu liniowego (GLM) dla prób zależnych ${ }^{1}$, porównania parami z poprawką Bonferroniego. Zestawiono oceny dokonane przez ojców, matki i nauczycieli na skalach inicjatywa, samokontrola, przywiązanie oraz zachowania niepokojące.

1 Ze względu na brak sferyczności danych (testy W Mauchly’ego $\mathrm{p}<0,05$ ) analizy przeprowadzono z korektą Greenhouse-Geisser. 


\section{INICJATYWA}

Wystąpiły istotne różnice między ojcami, matkami a nauczycielami w ocenie inicjatywy $(\mathrm{F}[1,834 ; 522,789]=13,341 ; \mathrm{p}<0,001)$. Porównania parami wykazały, że inicjatywa była oceniana przez matki $(M=29,1 ; S E=0,48)$ wyżej niż przez ojców $(\mathrm{M}=26,7 ; \mathrm{SE}=0,67 ; \mathrm{p}<0,001)$ oraz nauczycieli $(\mathrm{M}=26 ; \mathrm{SE}=0,47 ; \mathrm{p}<0,001)$. Ojcowie i nauczyciele nie różnili się w ocenie inicjatywy dzieci ( $\mathrm{p}=1,0$ po korekcie Bonferroniego). Różnice przedstawiono na wykresie 1.

Wykres 1. Ocena inicjatywy przez matki, ojców i nauczycieli

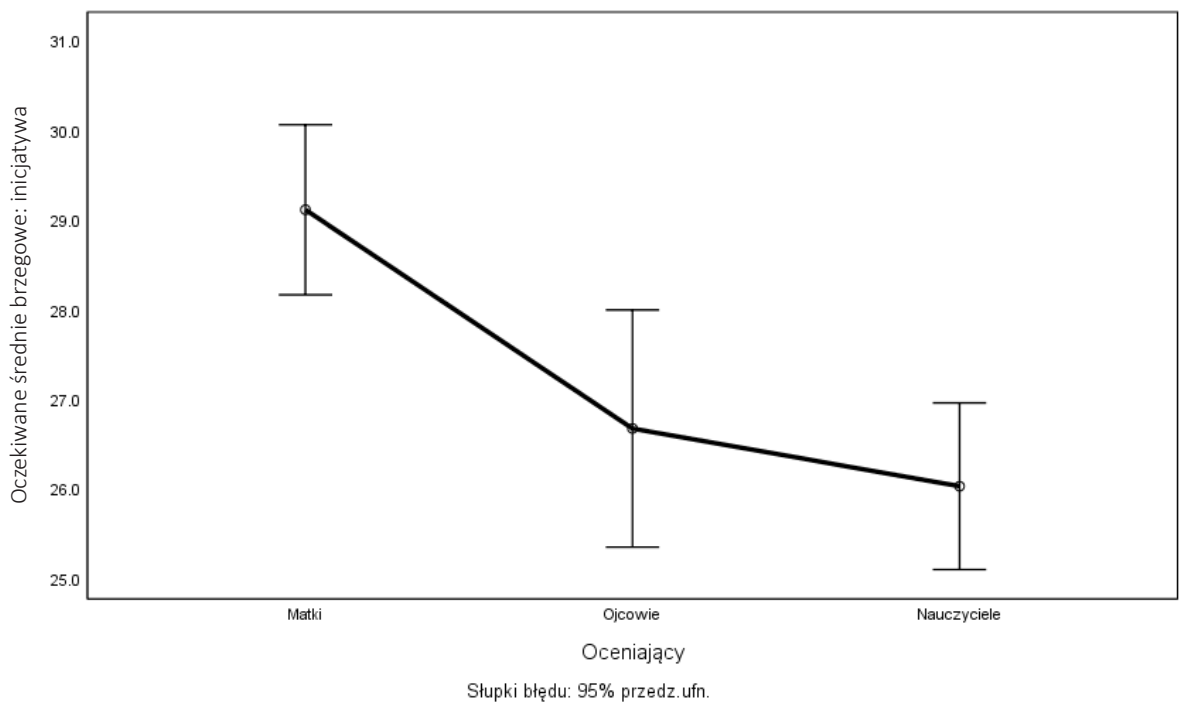

Różnice w otrzymanych rezultatach mogą wynikać z odmiennego kontekstu sytuacyjnego. Matki najczęściej obserwują swoje dzieci w warunkach domowych, w sytuacjach codziennych i zabawowych, kiedy to dzieci mają prawdopodobnie najwięcej okazji do przejawiania inicjatywy. Nauczyciele widzą swoich podopiecznych w odmiennym otoczeniu, często w sytuacjach zajęć i zabaw zorganizowanych oraz aktywności wymagających dostosowania się do panujących norm i zasad, jak również podążania za poleceniami osoby prowadzącej. Wynik uzyskany w grupie ojców można tłumaczyć na ogół krótszym czasem spędzanym przez nich wspólnie z dzieckiem bądź mniejszą swobodą zachowania dziecka w obecności ojcowskiego autorytetu. Ojcowie w porównaniu do matek mogą także rzadziej zachęcać dziecko do przejawiania inicjatywy. 


\section{SAMOKONTROLA}

Stwierdzono obecność istotnych różnic między ojcami, matkami a nauczycielami w ocenie samokontroli $(\mathrm{F}[1,829 ; 517,657] \mathrm{o} 9=16,004 ; \mathrm{p}<0,001)$. Porównania parami wykazały, że samokontrola była oceniana przez ojców $(M=18,2 ; \mathrm{SE}=0,44)$ istotnie niżej niż przez matki $(\mathrm{M}=20,1 ; \mathrm{SE}=0,33 ; \mathrm{p}<0,001)$ i przez nauczycieli $(\mathrm{M}=20,4 ; \mathrm{SE}=0,34 ; \mathrm{p}<0,001)$. Różnice $\mathrm{w}$ ocenie samokontroli między matkami a nauczycielami nie były znaczące ( $\mathrm{p}=1,0$ po korekcie Bonferroniego). Wyniki przedstawiono na wykresie 2.

Wykres 2. Ocena samokontroli przez matki, ojców i nauczycieli

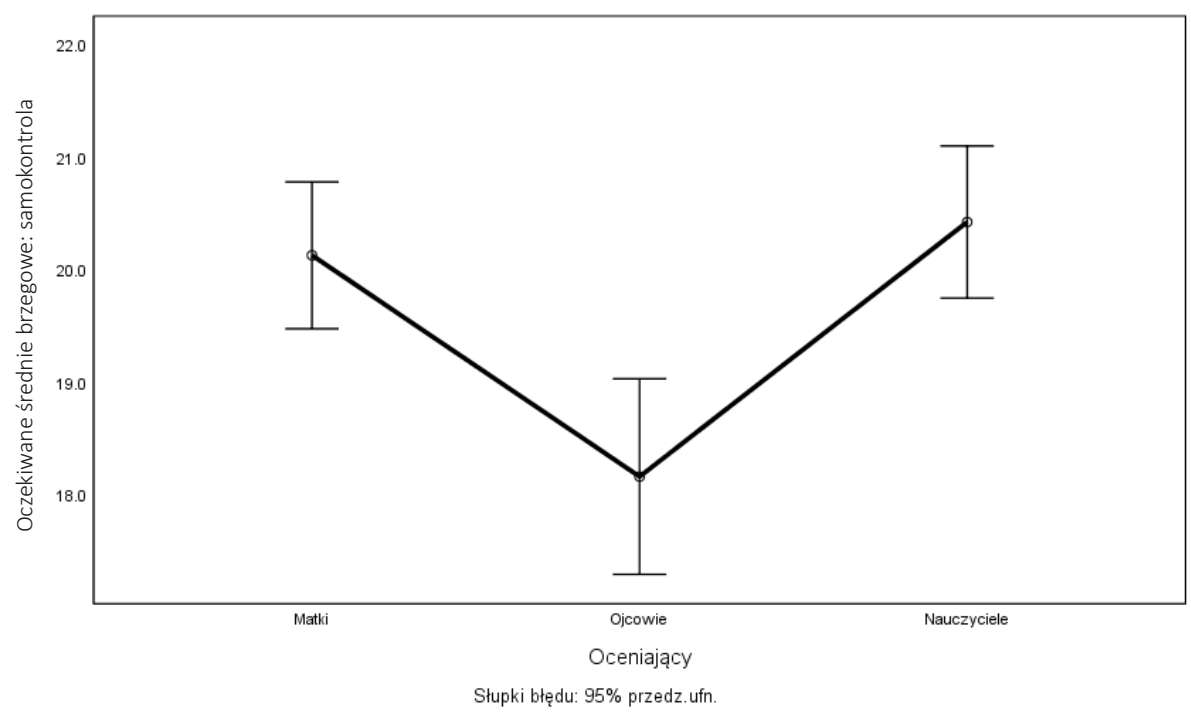

Uzyskany wynik wskazuje na wyższe wymagania w zakresie samokontroli dzieci u ojców w porównaniu z nauczycielami. Można to interpretować realnymi oczekiwaniami nauczycieli, którzy mają wieloletnie doświadczenie i wiedzę o typowym rozwoju dziecka.

\section{PRZYWIAZZANIE}

Dane wskazały istnienie istotnych różnic między ojcami, matkami a nauczycielami $\mathrm{w}$ ocenie przywiązania $(\mathrm{F}[1,815 ; 555,540]=52,434 ; \mathrm{p}<0,001)$. Porównania parami wykazały, że przywiązanie było oceniane przez matki najwyżej $(\mathrm{M}=25,8 ; \mathrm{SE}=0,37)$, nieco niżej przez ojców $(M=23,3 ; S E=0,5)$, a najniżej przez nauczycieli $(M=20,2$; $\mathrm{SE}=0,45)$. Wszystkie różnice były istotne statystycznie z $\mathrm{p}<0,001$. Wyniki przedstawiono na wykresie 3 . 
Wykres 3. Ocena przywiązania przez matki, ojców i nauczycieli

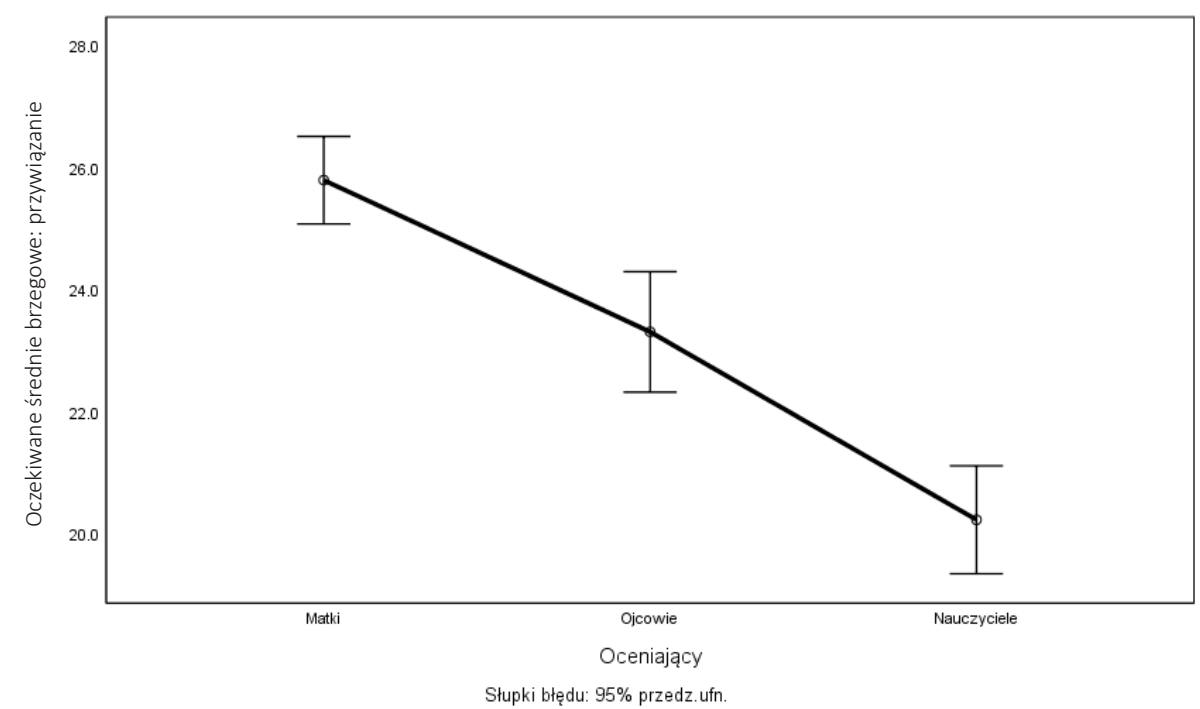

Uzyskany wynik obrazuje oczekiwana prawidłowość - silniejszego przywiązania dziecka do rodziców niż do nauczyciela. W toku rozwoju to kontakt z rodzicami i ich opieka powinny budować w dziecku bezpieczną więź.

\section{ZACHOWANIA NIEPOKOJACE}

Różnice między ojcami, matkami a nauczycielami w ocenie zachowań niepokojących okazały się istotne statystycznie $(\mathrm{F}[1,756 ; 537,454]=5,052 ; \mathrm{p}<0,009)$. Porównania parami wykazały, że zachowania niepokojące były oceniane przez nauczycieli istotnie najniżej $(M=10,8$; $\mathrm{SE}=0,43) \mathrm{w}$ porównaniu z matkami $(\mathrm{M}=12,2 ; \mathrm{SE}=0,33 ; \mathrm{p}=0,007)$. Ocena zachowań niepokojących przez ojców plasowała się pośrodku $(\mathrm{M}=11,3 ; \mathrm{SE}=0,35)$ i nie była istotnie różna od oceny dokonanej przez nauczycieli ( $\mathrm{p}=0,939$ po korekcie), ale była istotnie niższa od oceny dokonanej przez matki ( $\mathrm{p}=0,045$ po korekcie). Wyniki przedstawiono na wykresie 4 . 
Wykres 4. Ocena zachowań niepokojących przez matki, ojców i nauczycieli

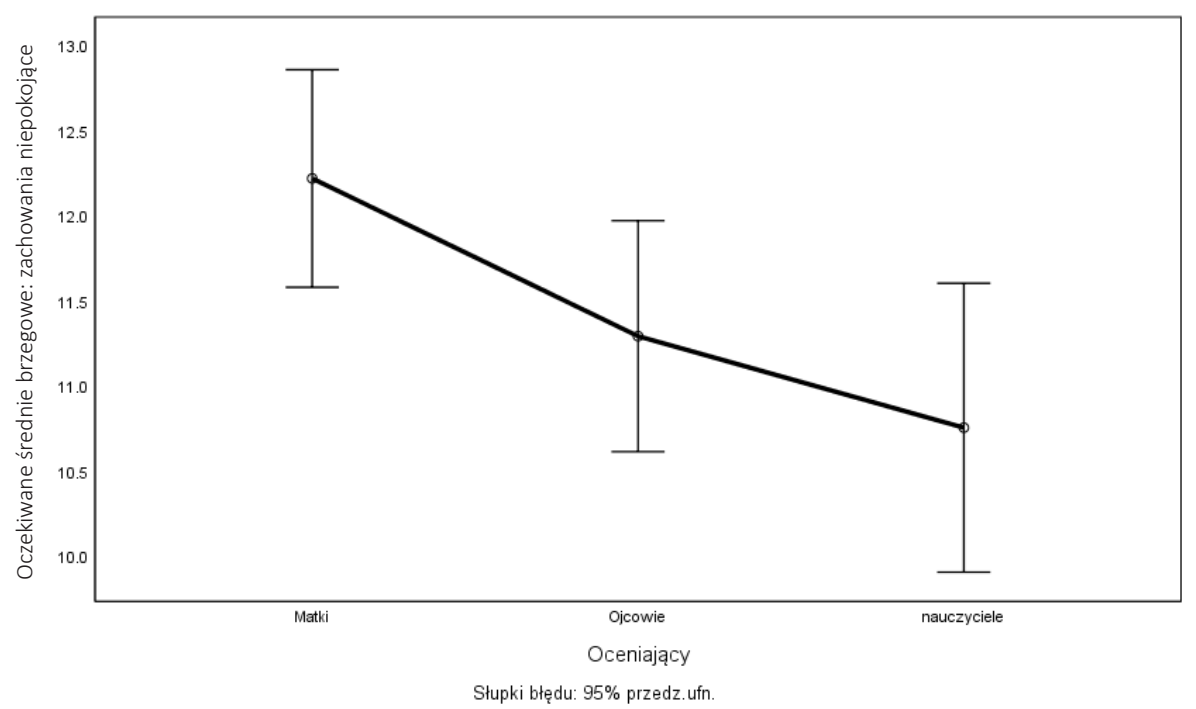

Nauczyciele w ocenie zachowań niepokojących u dzieci mogą wykazywać większą tolerancję od rodziców z uwagi na wiedzę o możliwościach występowania konfliktów w sytuacjach frustracji, o które łatwo w grupie rówieśniczej. Matki dużo bardziej zwracają uwagę na ewentualne sygnały zachowań niepokojących, co może się wiązać z ich oczekiwaniami „grzecznego” zachowania dziecka. Uzyskane wyniki mogą także wynikać z faktu, że matki poświęcają dziecku więcej indywidualnego czasu niż ojcowie oraz nauczyciele i są w związku z tym bardziej wrażliwe zarówno na przejawy zachowań pożądanych, jak i niepojących.

Dalsze analizy (mieszane ogólne modele liniowe z podziałem dzieci na chłopców i dziewczynki) wykazały, że oceny inicjatywy nie różnią się względem płci $(\mathrm{p}=0,065)$ ani nie jest istotna interakcja płci z oceniającym $(\mathrm{p}=0,122)$. Dla samokontroli również płeć ( $\mathrm{p}=0,117)$ i jej interakcja $\mathrm{z}$ oceniającym $(\mathrm{p}=0,137)$ nie była istotna. Dla przywiązania także nie stwierdzono efektu prostego $(p=0,292)$ ani interakcji $(p=0,228)$.

Dla zachowań niepokojących zarówno płeć dziecka $(\mathrm{p}=0,01)$, jak i interakcja płci z oceniającym ( $\mathrm{p}=0,002)$ okazały się czynnikami istotnymi statystycznie. Co interesujące, ważne różnice w ocenie zachowań niepokojących między chłopcami $(\mathrm{M}=12,2$; $\mathrm{SE}=0,565)$ a dziewczynkami $(\mathrm{M}=8,9 ; \mathrm{SE}=0,63)$ ujawniły się tylko w ocenach nauczycieli ( $<<0,001$ ), podczas gdy matki (dziewczynek: $\mathrm{M}=12,2 ; \mathrm{SE}=0,49$; chłopców: $\mathrm{M}=12,3, \mathrm{SE}=0,44)$ nie wykazywały istotnych różnic w ocenach $(\mathrm{p}=0,898)$, nie wykazywali ich też ojcowie (dziewczynek: $M=11,0 ; \mathrm{SE}=0,52$; chłopców: $\mathrm{M}=11,5$; $\mathrm{SE}=0,46 ; \mathrm{p}=0,479)$. 
Uzyskany wynik mógłby wskazywać na tendencję nauczycieli do spostrzegania chłopców w sposób bardziej stereotypowy jako mniej grzecznych niż dziewczynki. Rodzice w naszym badaniu nie ujawniają takich skłonności.

\section{Dyskusja}

Uzyskane wyniki potwierdziły opisywaną w literaturze przedmiotu tendencję do rozbieżności ocen możliwości dziecka przez rodziców a przez nauczyciela oraz wykazały różnice w ocenie dziewczynek i chłopców.

Odpowiedź na pierwsze pytanie badawcze pozwala na wskazanie różnic w zakresie zarówno czynników ochronnych, jak i czynników ryzyka. Wysoka ocena inicjatywy dzieci przez matki jest wynikiem optymistycznym: pokazuje, że w bezpiecznych warunkach domowych dziecko swobodnie prezentuje nowe pomysły, podejmuje decyzje, jest aktywne i spontaniczne. Wynik ten obrazuje przejaw możliwości rozwojowych dziecka w sprzyjających warunkach, co jest widoczne dla bacznego obserwatora, jakim jest matka. Również ojcowie oceniają inicjatywę dziecka wyżej od nauczycieli, jednak niżej niż matki, co może wynikać z mniejszej liczby obserwacji czynionych przez ojców. Warunki przedszkola stanowią już większe wyzwanie dla inicjatywy dziecka nowość środowiska i osób, ocena społeczna, stres. Szczególnie ustrukturowany charakter edukacji, stały rytm dnia i zajęć mogą wpływać na zmniejszenie się przestrzeni dla samodzielnych działań i decyzji dziecka.

W inicjatywie wyraża się poczucie skuteczności własnej dziecka, a więc przekonania o posiadaniu wpływu na własne życie, możliwości bycia sprawczym, autorem własnych działań. $\mathrm{Z}$ punktu widzenia zdrowia psychicznego jest to bardzo ważny wymiar ludzkiego funkcjonowania (Constantine i in. 1999; Masten 2001; Fergus i Zimmerman 2005).

Kolejnym czynnikiem ochronnym jest samokontrola, której poziom również został odmiennie oceniony przez dorosłych. Uzyskany wynik wskazuje na wyższe wymagania w zakresie samokontroli dzieci u ojców w porównaniu z matkami i nauczycielami. Pierwszym wymiarem różnicującym oceniających jest płeć (wszyscy nauczyciele byli kobietami), a więc można przyjąć, że oczekiwania mężczyzn różniły się w zakresie kontrolowania własnych zachowań czy respektowania norm przez dzieci. Może to wskazywać na wyższe standardy i wymagania u ojców. Drugi wymiar różnicujący oceniających to znajomość dziecka i ilość czasu spędzanego z nim. Można założyć, że nauczycielki i matki obserwują dziecko w większej liczbie sytuacji oraz towarzyszą mu częściej. Fakt, że ocena matek i nauczycielek jest podobna, może wskazywać na rzetelny szacunek tego zasobu u dzieci. Samokontrola jest czynnikiem podstawowym dla odporności psychicznej - wiąże się ze świadomością swoich emocji, 
pozwala na harmonijne współżycie z otoczeniem społecznym (Masten 2001; Sawyer, Miller-Lewis, Searle, Sawyer i Lynch 2015).

Przywiązanie jako trzeci czynnik ochronny zostało ocenione wyżej przez rodziców niż przez nauczyciela. Oznacza to, że silna, bezpieczna więź łączy dziecko przede wszystkim z matką, następnie z ojcem, a w dalszej kolejności z nauczycielem. W toku rozwoju to kontakt z rodzicami i ich opieka powinny budować w dziecku bezpieczną więź, a więc otrzymany wynik potwierdza prawidłowość rozwojową (Grotberg 2000; Ahnert 2010). Dzieci o niezaspokojonej w domu rodzinnym potrzebie bliskości przenoszą ją czasem na osobę nauczyciela, co jest widoczne w relacji z nim w przedszkolu.

Oprócz pozytywnych zasobów wspierających radzenie sobie ze stresem i wyzwaniami w zakresie odporności psychicznej analizowane są też czynniki ryzyka wynikające z cech temperamentu, nabytych zachowań czy innych trudności. Uzyskane w badaniu wyniki wykazały, że nauczyciele zauważyli istotnie mniej zachowań trudnych u dzieci niż matki. Pierwszym wyjaśnieniem wyniku może być większa wiedza i doświadczenie nauczycieli w temacie zachowań typowych dziecka w wieku przedszkolnym. Nauczyciele mogą spostrzegać większy zakres zachowań dziecka jako prawidłowy niż rodzice, którzy mają odmienne oczekiwania odnośnie do „grzecznego” dziecka. Drugie wyjaśnienie to modyfikacja zachowań dziecka w sytuacji ekspozycji społecznej, nowego środowiska i mobilizacji w grupie. Środowisko przedszkola ze swoją struktura i zasadami ułatwia dziecku orientację w oczekiwaniach społecznych i może być pomocne w opanowaniu stresu (Fefer i Lauterbach 2017).

Odnosząc się do drugiego pytania badawczego, można zauważyć, że płeć dziecka nie różnicowała ocen u żadnego z dorosłych w zakresie inicjatywy, samokontroli czy przywiązania dziecka. W zakresie zachowań niepokojących stwierdzono natomiast tendencję nauczycieli do spostrzegania chłopców w sposób stereotypowy jako mniej grzecznych niż dziewczynki. Nauczyciele obserwowali więcej zachowań związanych z wybuchami złości, niszczeniem przedmiotów, używaniem wulgaryzmów czy biciem innych u chłopców. W ocenach dokonywanych przez rodziców nie stwierdzono takiej tendencji. Wyniki naszych badań są sprzeczne z innymi doniesieniami, w których dorośli oceniali chłopców lepiej niż dziewczynki (Kärkkäinen 2011). Może to wynikać z odmiennego kontekstu społeczno-kulturowego (cytowane badania były prowadzone w Finlandii), który wpływa na sposób angażowania się w role związane z płcią. Świadomość stereotypów dotyczących zachowań typowych dla kobiet i mężczyzn w danej kulturze obserwuje się już u 5-latków - polskie przedszkolaki mężczyznom przypisywały siłę i agresywność, a kobietom słabość i łagodność (Garbula 2009). Można więc wysnuć hipotezę, że już u dzieci w wieku przedszkolnym w związku z wykształcaniem się tożsamości płciowej widać zachowania typowe dla płci kulturowej, co przekłada się na występowanie większej liczbie zachowań problemowych u chłopców. Badania pokazują, że chłopcy w porównaniu do dziewczynek częściej przejawiają 
problemy eksternalizacyjne, w tym zaburzenia opozycyjne i zachowania, które są bardziej widoczne (Kristoffersen i Smith 2015).

\section{Podsumowanie}

Analiza uzyskanych wyników pozwoliła na udzielenie twierdzącej odpowiedzi na obydwa postawione pytania badawcze. Okazało się, że wiedza matek, ojców i nauczycieli na temat zasobów odporności psychicznej dziecka różni się w istotny sposób. Matki postrzegają swoje dzieci jako przejawiające więcej inicjatywy i zachowań przywiązaniowych, ale także dostrzegają więcej zachowań niepożądanych. Ojcowie zdają się mieć większe wymagania wobec własnych dzieci, oczekując od nich większej zdolności do samokontroli. W porównaniu do matek i nauczycielek, widzą u dzieci mniej zasobów (inicjatywy, zachowań przywiązaniowych), ale i mniej zachowań niepokojących. Oczekiwania nauczycieli zdają się natomiast wynikać z ich wiedzy na temat prawidłowości rozwojowych oraz doświadczenia i możliwości porównywania zachowania dziecka z jego rówieśnikami. Postrzegają dzieci jako przejawiające mniej zachowań niepokojących i bardziej skłonne do samokontroli, ale za to o mniejszym poziomie inicjatywy i przywiązania. Może to także wynikać z odmiennego zachowania dziecka w środowisku przedszkolnym i domowym oraz z wpływu czynników społecznych.

Sposób oceny zachowania dziewczynek i chłopców różnił się jedynie w odniesieniu do zachowań niepokojących i to wyłącznie przez nauczycieli. Okazało się, że nauczycielki mogą postrzegać chłopców bardziej stereotypowo jako mniej grzecznych niż dziewczynki. Może to także wynikać z faktu, że skale obserwacyjne dla dzieci w wieku przedszkolnym są bardziej czułe na zachowania problemowe chłopców (zachowania niszczycielskie, opozycyjne, bójki) niż dziewczynek.

Uzyskane przez nas wyniki pokazują, jak bardzo kontekst społeczny i perspektywa dorosłego mogą wpływać na sposób postrzegania i oceniania dzieci w okresie przedszkolnym. Zrozumienie źródeł oraz natury tych rozbieżności może ułatwić komunikację między rodzicami i nauczycielami. Rezultaty prowadzonych badań podkreślają także znaczenie i konieczność dokonywania kompleksowego opisu zachowania dziecka, uwzględniającego jego mocne i słabe strony. Poszukiwanie zasobów, które pomogą zrównoważyć posiadane deficyty, jest szczególnie istotne w rozwijaniu i wzmacnianiu odporności psychicznej dziecka. Uzyskane w badaniu wyniki mogą się okazać użyteczne w procesie kształcenia nauczycieli jako wsparcie nabywania przez nich wiedzy o rozwoju dziecka, która jest bardzo ważna w rozpoznawaniu ewentualnych trudności czy zaburzeń. Ponadto wyniki ukazujące rozbieżność w ocenie tego samego dziecka przez różnych dorosłych wskazują na konieczność ścisłej współpracy rodziców i nauczycieli. Każdy z nich, obserwując dziecko w innych warunkach i innym czasie, posiada cenne 
informacje, którymi może się podzielić, szczególnie w sytuacji stawiania diagnozy czy wyjaśniania wątpliwości co do prawidłowego rozwoju młodego człowieka.

\section{Bibliografia}

Ahnert L. (2010). Wieviel Mutter braucht ein Kind? Bindung-Bildung-Betreuung: öffentlich und privat, Heidelberg: Spektrum, Akademischer Verlag.

Ansari A., Winsler A. (2014). Montessori Public School Pre-K Programs and the School Readiness Low Income Black and Latino Children, ,Journal of Educational Psychology”, nr 4(106), s. 1066-1079.

Birch S., Ladd G. (1997). The Teacher - Child Relationship and Children's Early School Adjustment, „Journal of School Psychology”, nr 35, s. 61-69.

Buchanan C., Eccles J., Flanagan C., Midgley C., Feldlaufer H., Harold R. (1990). Parents' and Teacher'sBeliefs about Adolescents: Effects of Sex and Experience, "Journal of Youth and Adolescence", nr 19, s. 363-394.

Constantine N., Benard B., Diaz M. (1999). Measuring Protective Factors and Resilience Traits in Youth: The Healthy Kids Resilience Assessment, „American Psychologist”, nr 55, s. 647-654.

Daniels D.H., Kalkman D., McCombs B. (2001). Young Children's Perspectives on Learning and Teacher Practices in Different Classroom Contexts, „Early Education and Development", nr 12, s. 253-273.

Daniels D.H., Shumow L. (2003). Child Development and Classroom Teaching: a Review of the Literature and Implications for Educating Teachers, „Applied Developmental Psychology", nr 23, s. 495-526.

Fefer S., Lauterbach A. (2017). Supporting Diverse Learners through Family-School Partnership: Perspectives from Parents and Educators. Sixth ENSEC (European Network for Social and Emotional Competence) Conference, Theme: Diversity, 7-9 June 2017. Stockholm, Sweden.

Fergus S., Zimmerman M.A. (2005). Adolescent Resilience: A Framework for Understanding Healthy Development in the Face of Risk, „Annual Review of Public Health”, nr 26, s. 399-419.

Fröhlich-Gildhoff K., Dörner T., Rönnau M. (2007/12). Prävention und Resilienzförderung in Kindertagseinrichtungen, München, Basel: Ernst Reinhardt.

Garbula J.M. (2009). Dzieci wobec stereotypów ptci, „Forum Oświatowe”, nr 1(40), s. 53-89.

Garmezy N. (1971). Vulnerability Research and the Issue of Primary Prevention, „American Journal of Orthopsychiatry", nr 41, s. 101-116.

Garmezy N. (1983). Stressors of childhood, [w:] N. Garmezy, M. Rutter (red.) i Center for Advanced Study in the Behavioral Sciences, Inc., Stress, Coping, and Development In Children, Baltimore, MD, US: Johns Hopkins University Press, s. 43-84.

Grotberg E. (2000). Zwiększanie odporności psychicznej, wzmacnianie sit duchowych, tłum. M. Karwowska-Struczyk, Warszawa: Wydawnictwo Akademickie „Żak”. 
Heszen I., Sęk H. (2007). Psychologia zdrowia, Warszawa: Wydawnictwo Naukowe PWN. Junik W. (red.). (2011). Resilience: teoria - badania - praktyka, Warszawa: Parpamedia.

Kaczmarek Ł. (2011). Skala Sprężystości Psychicznej - polska adaptacja Ego Resiliency Scale, „Czasopismo Psychologiczne”, nr 17, s. 263-265.

Kärkkäinen R. (2011). Doing Better? Children's and Their Parents' and Teachers' Perceptions of the Malleability of the Child's Academic Competences. Dissertations in Education, „Humanities and Theology”, nr 14, Joensuu: University of Eastern Finland.

Katz L. (1997). Child Development Knowledge and Teachers of Young Children, Champaign IL: ERIC Publications.

Kawecki I. (2013). Wiedza i umiejętności początkującego nauczyciela w świetle poglądów Lindy Darling-Hammond, „Debata Edukacyjna”, nr 6, s. 88-96.

Kielar-Turska M. (1997). Orientacja dorostych w rozwoju dziecka, [w:] W. Pilecka, M. Kliś (red.), Funkcje psychologii $w$ dobie przemian spoteczno-kulturowych $w$ Polsce, Kraków: Wydawnictwo Naukowe WSP, s. 9-20.

Knap-Stefaniuk A. (2017). Wyzwania we wspótczesnej edukacji-znaczenie wiedzy z zakresu psychologii rozwojowej, nowe role nauczyciela $i$ ksztatcenie dorostych, „Kwartalnik Naukowy Uczelni Vistula”, nr 2(55), s. 197-213.

Kristoffersen J.H.G., Smith N. (2015). Gender Differences in Behavioral Problems and School Outcomes, „Journal of Economic Behavior and Organization”, nr 115, s. 75-93.

LeBuffe, P.A., Naglieri, J.A. (1999). The Devereux Early Childhood Assessment (DECA): Ameasure of Within-child Protective Factors in Preschool Children, „National Head Start Association Dialog”, 3, 75-80.

LeBuffe P.A., Shapiro V.B. (2004). Lending "strength" to the Assessment of Preschool Social-emotional Health, "The California School Psychologist”, nr 9, s. 51-61.

Luthar S.S. (1991). Vulnerability and Resilience: A Study of High-risk Adolescents, „Child Development”, nr 62, s. 600-616.

Masten A. (2001). Ordinary Magic. Resilience Process in Development, „American Psychologist", nr 56(3), s. 227-238.

Masten A., Obradović J. (2006). Competence and Resilience in Development, „Annals of the New York Academy of Sciences", nr 1094, s. 13-27.

Ogg J.A., Brinkman T.M., Dedrick R.F., Carlson J.S. (2010). Factor Structure and Invariance Across Gender of the Devereux Early Childhood Assessment Protective Factor Scale, „School Psychology Quarterly”, nr 25(2), d. 107-118.

Ogińska-Bulik N., Juczyński Z. (2011). Prężność u dzieci i mtodzieży: charakterystyka i pomiar-polska skala SPP-18, „Polskie Forum Psychologiczne”, nr 16(1), s. 7-28.

Okagaki L., Sternberg R.J. (1993). Parental Beliefs and Children's School Performance, „Child Development”, nr 64(1), s. 36-56.

Oliva A., Palacios J. (1992). Ideas de los Profesores sobre la Education y el Desarrollo [Teacher's Ideas onEeducation and Development], Sevilla: Universida de Sevilla. Psicologia.

Olsson C.A., Bond L., Burns J.M., Vella-Brodrick D.A., Sawyer S.M. (2003). Adolescent Resilience: a Concept Analysis, „Journal of Adolescence”, nr 26, s. 1-11.

Pianta R., Sternberg M. (1992). Teacher - Child Relationship and the Process of Adjusting to School, [w:] W. Damon, R. Pianta (red.), Beyond the Parent: the Rrole of other Adults 
in Children's Lives: Vol. 57. New Directions for Child Development, San Francisco: Jossey-Bass, s. 61-79.

Rahmawati A., Tarias M.M.W., Nawangsari N.A.F. (2018). Children's School Readiness Based on Teachers' and Parents' Perceptions, „International Journal of Pedagogy and Teacher Education", nr 2(1), s. 201-212.

Rutter M. (2006). Implications of Resilience Concepts for Scientific Understanding, „Annals of the New York Academy of Sciences", nr 1094, s. 1-12.

Sawyer A.C.P, Miller-Lewis L.R., Searle A.K., Sawyer M.G., Lynch J.W. (2015). Is Greater Improvement in Self-regulation Associated with Fewer Behavioral Problems Later in Childhood?, „Developmental Psychology”, nr 51(12), s. 1740-1755.

Sikorska I. (2016). Odporność psychiczna w okresie dziecinstwa, Kraków: Wydawnictwo Uniwersytetu Jagiellońskiego.

Sikorska I., Sajdera J., Paluch-Chrabąszcz M. (2017). Dzielne Dzieci! Jak wspierać odporność psychiczna dziecka w wieku przedszkolnym, Kraków: Wydawnictwo Edukacyjne.

Szada-Borzyszkowska J. (2008). Sytuacja dziecka zdolnego w szkole, [w:] M. Wróblewska (red.), Ksztatcenie i promowanie uczniów zdolnych, Białystok: Trans Humana Wydawnictwo Uniwersyteckie, s. 90-99.

Werner E.E., Smith R.S. (1992). Overcoming the Odds: High Risk Children from Birth to Adulthood, Ithaca: Cornell University Press.

Werner E.E., Smith R.S. (2001). Journeys from Childhood to Midlife: Risk, Resilience, and Recovery, Ithaca: Cornell University Press.

Wustmann C. (2004). Resilienz: Widerstandsfähigkeit von Kindern in Tageseinrichtungen fördern, Weinheim, Basel: Beltz.

ADRES DO KORESPONDENCJI

dr Iwona Sikorska

Instytut Psychologii Stosowanej

Uniwersytet Jagielloński

e-mail: i.sikorska@uj.edu.pl

mgr Magdalena Adamczyk-Banach

Instytut Psychologii Stosowanej

Uniwersytet Jagielloński

e-mail: magdalena.adamczyk@doctoral.uj.edu.pl

dr Mateusz Polak

Instytut Psychologii Stosowanej

Uniwersytet Jagielloński

e-mail: mateusz.polak@uj.edu.pl 